\title{
PHENOTYPIC CORRELATIONS BETWEEN EGG WEIGHT AND SOME EGG QUALITY TRAITS IN THREE VARIETIES OF JAPANESE QUAIL (Coturnix coturnix japonica) \\ ${ }^{*}$ Chimezie, V. O., Fayeye, T. R., Ayorinde, K. L. and Adebunmi, A. \\ Department of Animal Production, \\ University of Ilorin Kwara State \\ Corresponding author: *ojo_victoria@yahoo.com
}

\begin{abstract}
This study was conducted to determine the relationship between egg weight and some egg quality traits in three varieties of Japanese quail. A total of 240 eggs (80 eggs/ plumage variety) obtained from 60 eight weeks old Japanese quails of three different plumage colour varieties: Pharaoh Quail (Black), A \& M white (White) and Manchurian Gold (Brown) at 8-14 weeks of age were used in this study. Eggs were examined for both internal and external egg quality traits.Data obtained were subjected to one-way analysis of variance using the general linear procedure of SAS (2012). Differences in means were ranked using the Duncan's multiple Range test. Phenotypic correlations between egg weight and other egg quality traits for each variety were also determined. Mean egg weight was significantly higher $(P<0.05)$ in the Brown variety $(10.53 \mathrm{~g})$ than in the Black and White varieties. Likewise the Brown variety was significantly higher $(P<0.05)$ in egg width, yolk weight, yolk diameter, shell weight albumen weight and height and egg index. Egg length, yolk height, shell thickness and Haugh unit however were not significantly influenced $(P>0.05)$ by plumage varieties. Egg weight was positively and significantly correlated with egg width, egg length all external traits measured in the three varieties and with all internal traits in the Black variety. However, egg weight was negatively correlated with albumen height (-0.023) and Haugh unit (-0.228) in the White and with Haugh unit (-0.209) in the Brown variety. The results on correlation suggest that egg weight could be used as an index of egg quality in Japanese quails. Further study is recommended to explain the genetic basis for the association between plumage gene and egg characteristics in different varieties of Japanese quail.
\end{abstract}

Keywords: Japanese quail, egg quality traits, phenotypic correlation 


\section{INTRODUCTION}

Japanese quails are the smallest poultry species raised for meat and egg production. In Nigeria, the quail egg has gained more popularity than the quail meat. The quail egg is prized as a dietary and healing food for man and several health benefits of quail egg have been reported in literature due to the essential nutrients they contain (Troutman, 2012).

The external and internal quality traits of the egg are significant in poultry breeding, especially for their influence on yield features of future generations, breeding performance, quality and growth of the chicks (Islam et al., 2001). Quality traits of egg determines price directly in commercial flocks and it is usually described in connection with consumers' requirements. In meat line quails, the productivity and quality of the egg has been reported as an important factor for economic breeding and propagation of the flock (Kumaril et al., 2008). Egg weight, shell weight, shell thickness, weight of egg yolk and albumen are the important egg traits influencing egg quality, when other management conditions and fertility are not the limiting factors (Khurshid et al., 2003).

Egg quality characteristics are influenced by many factors, including genetic and environmental ones (Bednarczyk, 1991). Genetic differences in egg quality characteristics have been reported to exist between species, and between breeds, strains and families within lines (Buss, 1982). Several studies have shown that hens with coloured feathers lay bigger eggs than hens with white feathers (Halaj and Grofik, 1994; Halaj and Golian, 2011; Sari et al., 2012). The effect of breed on some egg quality traits of laying hen have also been reported by Hanusova et al. (2015) and the direct influence of age and plumage genotype of Japanese quail on their egg quality have been reported by Sari et al. (2012). Kul and Seker, (2004) had reported positive correlations between some external and internal egg quality traits in Japanese quail and Ojedapo, (2013) have also reported the possibility of determining some external egg quality traits from egg weight of Pharaoh (Black variety) quail. Several varieties of Japanese quail have been identified in the Sub-Saharan Africa. However there is dearth of information on the possible effect of plumage colour and the relationship between egg weight and other egg quality traits among varieties of Japanese quail in the sub-Saharan environment. The study therefore examined the phenotypic correlations between egg weight and some egg quality traits in three varieties of Japanese quail in Nigeria. 


\section{MATERIALS AND METHODS}

\section{Experimental site}

The experiment was carried out at the Poultry unit, Faculty of Agriculture Teaching and Research farm, University of llorin, Kwara state, Nigeria.

\section{Experimental birds and Management}

The quails used for this experiment were selected from an existing Black, Brown and White plumage variety flocks at the Faculty of Agriculture Teaching and Research farm, University of llorin. A total of 60 (20 birds / treatment) eight weeks old laying Japanese quails were selected and raised under similar management techniques for eight weeks. The birds were housed separately based on plumage colour. The birds were fed, ration containing $18 \%$ crude protein and $2700 \mathrm{kcal} \mathrm{ME} / \mathrm{kg}$ diet from 5 weeks till the end of the experiment which lasted for 8 weeks. Feed and water were supplied ad libitum.

\section{Data collection and Analysis}

The data collected for external and internal egg quality traits were taken on 240 eggs; Brown (80), Black (80), and White (80), respectively. Determination of internal and external egg quality traits were carried out immediately after collection. Internal and external egg quality traits measured includes egg weight egg length; egg width; egg index; yolk weight; yolk height; yolk diameter; yolk index; shell weight shell thickness albumen height; albumen width and Haugh unit.

Digital electronic scale was used in weighing the eggs. Egg length and width were measured with the aid of a pair of vernier caliper $(\mathrm{mm})$. The values of Egg length and Egg weight were used to determine the Eggs index. The thickness of each shell was determined using the micrometer screw gauge $(\mathrm{mm})$. The yolk and albumen height and width were determined by using a spherometer calibrated in $(\mathrm{mm})$ Accuracy of shell thickness was determined by measuring shell samples at the broad and middle portion and narrow end of the shell. The average shell thickness was then recorded in $(\mathrm{mm})$. The egg shape index and Haugh unit were calculated using the formulae below:

Egg shape index $(\%)=[$ width $(\mathrm{cm}) /$ length $(\mathrm{cm})] \times 100 \%$

Haugh unit $(H . U)=100 \log .\left(H+7.57-1.7 W^{0.37}\right)$ 
Where; H.U = Haugh Unit

$\mathrm{H}=$ Observed albumen height

W $=$ Observed weight of egg in gram

\section{Statistical analysis}

Data collected were subjected to one way analysis of variance-ANOVA model for completely randomized design (CRD), using the general linear procedure of SAS (2012). Significant differences between means were separated using the Duncan Multiple Range Test.

Correlation analysis was also used to determine the relationship between external and internal egg quality traits for each plumage variety using the same procedure of SAS (2012).

\section{RESULTS AND DISCUSSION}

Table 1 shows the results of the effect of plumage colour variety on the external egg quality traits in Japanese quail. The result showed that plumage colour had a significant effect on most of the parameters measured except for the egg length and shell thickness which showed no significant differences ( $p>0.05$ ) among treatment means. The mean egg weight was significantly higher $(p<0.05)$ in the Brown variety $(10.53 \mathrm{~g})$ than the Black $(9.95 \mathrm{~g})$ and the White $(9.82 \mathrm{~g})$ varieties with no significant differences $(p>0.05)$ between the Black and the White. Egg width, egg index and shell weight also followed the same trend with the Brown having significantly higher $(p<0.05)$ values of $2.0 \mathrm{~cm}, 79.43 \%$ and $0.96 \mathrm{~mm}$ respectively. From the point of view of consumers, egg weight is regarded as the most important quality trait (Genchev, 2012), thus the possibility of higher preference for eggs from Brown variety than from the other varieties. Moreover, positive correlations between egg weight and chick hatch weight have been reported (Ojo et al., 2012), larger egg size in the Brown variety may therefore be of advantage in quail breeding industry. The values obtained in this study for quail egg weight are however similar to those reported by Dudusola, (2010) and Ojo et al. (2011) but lower than the values reported by Seker et al. (2005) and Sezer, (2007). Positive relationship have been reported between body weight and egg weight in many breeds of poultry (Ayorinde et al., 1988; Sola-Ojo et al., 2011 and Ojo et al., 2011) the lower egg weight reported in this study may therefore be as a result of the characteristic lower body weight of the birds in this region compared to those in other studies. 
The significant effect of plumage colour on egg shell weight agrees with the reports of Sari et al. (2012) who also reported a significant influence of plumage colour on shell weight. Though values obtained for egg shell weight in this study was lower than those reported by Sari et al. (2012) who reported higher shell weight of $1.27 \mathrm{~g}$, but falls within the value reported by Altan et al. (1998). The significantly higher shell weight in the Brown variety than in the Black and White varieties however negates the authors' report of higher shell weight in the White than in other plumage varieties. The values obtained for egg shell thickness falls within the range of $0.20-0.30 \mathrm{~mm}$ reported by Uluocak et al. (1995), Erensaymn and Camcm, (2002), Ojo et al.(2011). The non significant effect of plumage colour on shell thickness also agrees with Sari et al. (2012). Egg shape index was significantly highest in the Brown (79.43\%) than the other varieties indicating a better shaped egg than in the other plumage varieties. The mean shape index values obtained from the Brown, White and Black plumage colour in this study were however similar to the values reported by Yilmaz and Caglayan (2008) and Yilmaz et al., (2011).

Table 1: Mean External Egg Quality Traits of Three Varieties of Japanese Quail

\begin{tabular}{llll}
\hline \multicolumn{3}{l}{ Plumage } & \multicolumn{2}{l}{ Colour Varieties } \\
\cline { 2 - 4 } Traits & Black & Brown & White \\
\hline Egg Weight (G) & $9.95 \pm 0.88^{\mathrm{b}}$ & $10.53 \pm 1.06^{\mathrm{a}}$ & $9.82 \pm 0.96^{\mathrm{b}}$ \\
Egg Length (G) & $2.50 \pm 0.12$ & $2.53 \pm 0.13$ & $2.53 \pm 0.15$ \\
Egg Width $(\mathbf{C m})$ & $1.89 \pm 0.14^{\mathrm{b}}$ & $2.00 \pm 0.16^{\mathrm{a}}$ & $1.91 \pm 0.11^{\mathrm{b}}$ \\
Yolk Weight $(\mathbf{G})$ & $3.03 \pm 0.45^{\mathrm{b}}$ & $3.34 \pm 0.44^{\mathrm{a}}$ & $2.99 \pm 0.40^{\mathrm{b}}$ \\
Yolk Height $(\mathbf{C m})$ & $9.01 \pm 1.02$ & $8.87 \pm 2.36$ & $9.17 \pm 1.35$ \\
Yolk Diameter (Cm) & $1.63 \pm 0.14^{\mathrm{b}}$ & $1.74 \pm 0.19^{\mathrm{a}}$ & $1.67 \pm 0.15^{\mathrm{b}}$ \\
Shell Weight $(\mathbf{G})$ & $0.94 \pm 0.14^{\mathrm{ab}}$ & $0.96 \pm 0.15 \mathrm{a}$ & $0.91 \pm 0.16^{\mathrm{b}}$ \\
Shell Thickness(Mm) & $0.27 \pm 0.06$ & $0.27 \pm 0.06$ & $0.27 \pm 0.06$ \\
Albumen Weight(G) & $5.19 \pm 0.73^{\mathrm{a}}$ & $5.16 \pm 0.73^{\mathrm{a}}$ & $4.88 \pm 0.67^{\mathrm{b}}$ \\
Albumen Height(Mm) & $2.77 \pm 0.68^{\mathrm{a}}$ & $2.79 \pm 0.62^{\mathrm{a}}$ & $2.55 \pm 0.69^{\mathrm{b}}$ \\
Egg Index (\%) & $75.85 \pm 4.38^{\mathrm{b}}$ & $79.43 \pm 4.39^{\mathrm{a}}$ & $76.12 \pm 5.92^{\mathrm{b}}$ \\
Haugh Unit (Hu) & $80.15 \pm 4.52$ & $79.81 \pm 4.50$ & $78.69 \pm 4.96$ \\
\hline a,bMeans with different superscript in the same row are significantly $(P<0.05)$ different .
\end{tabular}


Table 2 shows the effect of plumage colour variety on the internal egg quality traits of Japanese quail. Plumage colour influenced all the parameters measured significantly $(p<0.05)$ except yolk height and Haugh unit. The brown variety was significantly higher $(p<0.05)$ than both the Black and the White varieties in yolk weight and diameter with no significant difference $(p>0.05)$ between the Black and the White varieties. Brown plumage quail was significantly higher $(p<0.05)$ than the White variety in albumen weight and height. The difference in values obtained for the same traits in Brown and Black varieties was not significant $(P>0.05)$. The Haugh unit was also not significantly $(p>0.05)$ influenced by plumage colour. Adeogun and Amole, (2004) had reported that the higher the Haugh unit and yolk index the more desirable is the interior quality of the egg. The values reported for internal egg quality traits in this study though lower than the reports of Sari et al., (2012) falls within the range reported for Japanese quail by Mignon-Grasteau and Minvielle, (2003) and Dudusola, (2010).

Table 2: Mean Internal Egg Quality Traits of Three Varieties of Japanese Quail

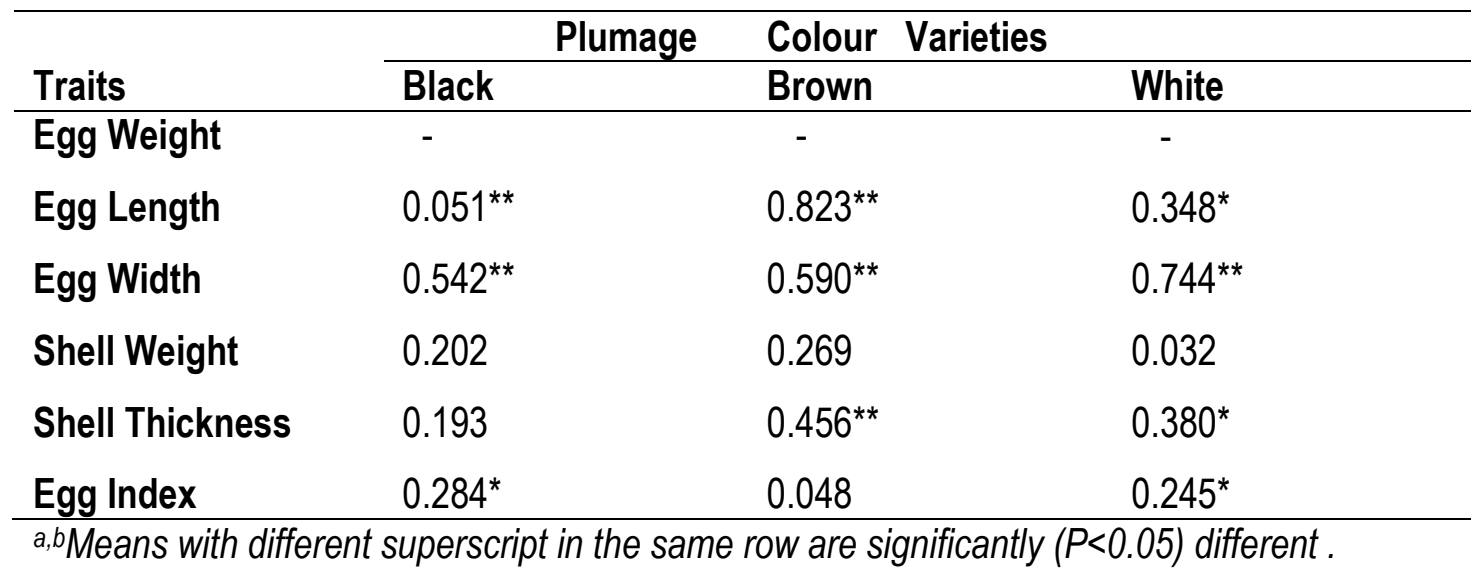

The result of the phenotypic correlations between egg weight and external egg quality traits in the Brown, Black and White varieties of Japanese quail is shown in Table 3. Phenotypic correlations were positive and significant $(p<0.01)$ between egg weight and egg width in all the three plumage varieties. Also egg weight was positively and significantly $(p<0.01)$ correlated with egg length in both Black and the Brown varieties but higher in the Brown $(0.823)$ and significant at $p<0.05$ in the White variety. Shell thickness was also significantly correlated with egg weight $(0.348)$ at $p<0.01$ in the Brown variety $(0.456)$ and $a t p<0.05$ in the 
White $(0.380)$ but not significant in the Black variety. Positive and significant $(p<0.05)$ correlations were also observed between egg weight and egg index in all the plumage varieties.

Table 3: Phenotypic Correlations between Egg Weight and other External Egg Quality Traits in Three Varieties of Japanese Quail

\begin{tabular}{|c|c|c|c|}
\hline \multirow{2}{*}{ Traits } & Plumage & \multicolumn{2}{|c|}{ Colour Varieties } \\
\hline & Black & Brown & White \\
\hline Yolk Weight & $0.402^{*}$ & $0.741^{* *}$ & $0.577^{* *}$ \\
\hline Yolk Height & 0.145 & 0.136 & 0.159 \\
\hline Yolk Diameter & $0.311^{*}$ & $0.327^{*}$ & $0.331^{*}$ \\
\hline Albumen Weight & $0.483^{* *}$ & $0.522^{* *}$ & $0.588^{* *}$ \\
\hline Albumen Height & 0.224 & 0.026 & -0.023 \\
\hline Haugh Unit & 0.032 & -0.209 & -0.228 \\
\hline
\end{tabular}

Table 4 shows the phenotypic correlations between egg weight and internal egg quality traits in three varieties of Japanese quails. Egg weight was positive and significantly $(p<0.01)$ correlated with yolk weight in the Brown and White varieties with the Brown having a higher value $(0.741)$. The same was positive and significant $(p<0.05)$ in the Black with a lower value of 0.402 . Yolk diameter was also positive and significantly $(p<0.05)$ correlated with egg weight in all the three plumage varieties. Moderate but positive and significant $(p<0.01)$ correlations were observed between egg weight and albumen weight in the Black (0.483), Brown (0.522) and the White (0.588) varieties. Phenotypic correlations between egg weight and yolk height, and between egg weight and albumen height in brown, black and white quails were generally negligible $(-0.023-0.224)$. Negative correlation was observed between egg weight and albumen height in the White variety. Haugh unit was also negatively correlated with egg weight in the Brown and the white varieties. The correlation between egg weight and haugh unit was however positive in the Black variety.

The significant positive correlations reported between egg weight and other egg quality traits in this study agrees with the report of Ojedapo, (2013) who reported positive correlations between egg weight and some other egg quality traits, though higher levels of correlation were reported in this study. It also supports the findings of Kul and Seker, (2004) who reported positive correlation between egg weight and other external and internal egg quality 
traits. The negligible correlations between egg weight and albumen height in the White and between egg weight and Haugh unit in the Brown and White varieties negates the result of Kul and Seker, (2004) who reported positive correlations between these traits.

Table 4: Phenotypic Correlations between Egg Weight and Internal Egg Quality Traits in Three Varieties of Japanese Quail

\begin{tabular}{|c|c|c|c|}
\hline \multirow[b]{2}{*}{ Traits } & \multicolumn{2}{|c|}{ Plumage } & Varieties \\
\hline & Black & Brown & White \\
\hline Egg Weight & - & - & - \\
\hline Yolk Weight & $0.402^{*}$ & $0.741^{* *}$ & $0.577^{* *}$ \\
\hline Yolk Height & 0.145 & 0.136 & 0.159 \\
\hline Yolk Diameter & $0.311^{*}$ & $0.327^{*}$ & $0.331^{*}$ \\
\hline Albumen Weight & $0.483^{* *}$ & $0.522^{* *}$ & $0.588^{* *}$ \\
\hline Albumen Height & 0.224 & 0.026 & -0.023 \\
\hline Haugh Unit & 0.032 & -0.209 & -0.228 \\
\hline
\end{tabular}

${ }^{* *}(P<0.01),{ }^{*}(P<0.05)$

\section{CONCLUSION}

It is concluded that Brown Japanese quail is superior in egg weight and in most of the egg quality traits measured. The results on correlation suggest that egg weight could be used as an index of egg quality in Japanese quails. Further study is recommended to explain the genetic basis for the association between plumage gene and egg characteristics in different varieties of Japanese quail.

\section{REFERENCES}

Adeogun, I. O. and Amole, F. O. (2004). Some quality parameters of exotic chicken eggs under different storageconditions. Bulletin of Animal Health and Production in Africa, 52: 43-47.

Altan, O., Oguz, I. and Akbas, Y. (1998): Effects of selection for high body weight and age of hen on egg characteristics in Japanese quail (Coturnix coturnix japonica). Turk J. Vet. Anim. Sci. 22, 467-473.

Ayorinde, K. L. Toye, A. A. and Aruleba, O. A. (1988). Association between body weight and some egg production traits in a strain of commercial layer. Nigerian Journal of Animal Production, 15: 119-121.

Bednarczyk, M. (1991). Eggs technology. Wyd. Nauk. Tech. Warszawa, (In Polish). 
Buss, E. G. (1982). Genetic differences in avian egg shell formation. Poult. Sci., 61: 20482055.

Dudusola, I. O.(2010). Comparative evaluation of internal and external qualities of eggs from qualities of eggs from quail and guinea fowl. I.R.J.P.S. 5: 112-115.

Erensaymn, C. and Camcm, O. (2002).Effects of the oviposition time on egg quality in quails. Arch Geflügelk, 66: 283-284.

Genchev, A. (2012). Quality and composition of Japanese quail eggs (coturnix japaonica). Trakia journal of sciences, 10 (2): 91-101.

Halaj, M. and Golian , J. (2011) Table eggs characteristics. Nitra: Garmond, pp.37-62 in Slovak)

Halaj M. and Grofik R. (1994) The relationship between egg shell strength and hens features. In Živočišná výroba, 39, pp. 27-934.

Hanusová, E., Hrnčár, C., Hanus, A. and Oravcová, M. (2015). Effect of breed on some parameters of egg quality in laying hens. Acta fytotechn. zootechn., 18, (1): 20-24.

Khurshid, A., M. Faroog, F.R. Durrani, K. Sarbiland, N. Chand, (2003) Predicting egg weight, shell weight, shell thickness and hatching weight of Japanese quail using various egg traits as regressors. International Journal of Poult. Sci. 2, 164-167.

Kul, S., and Seker, I. (2004). Phenotypic correlations between some external and internal egg quality traits in the Japanese quail (Coturnix coturnix japonica). International Journal of Poultry Science, 3 (6) 400-405.

Kumaril, P., Gupta, B. R., Prakash, B. G. and Reddy, M. R. A. (2008). A study of egg quality traits in Japanese quails. Journal of Veterinary and Animal Sciences 4 (6): 227-231.

Mignon-Grasteau, S., F. Minvielle, (2003): Relation between tonic immobility and production estimated by factorial correspondence analysis in Japanese quail. Poult. Sci. 82, 18391844.

Ojedapo, L. O. (2013). Phenotypic correlation between the external and internal egg quality traits of pharaoh quail reared in Derived Savanna Zone of Nigeria. Journal of Biology, Agriculture and Healthcare, 3 (10).

Ojo, V., Ayorinde, K. L. and Fatoki, H. O. (2011). Relationship between Bodyweight and some Egg Production Traits in the Japanese Quail (Cortunix cortunix japonica). Nigerian Society of Experimental Biology (NISEB) Journal, 11(2): 89 - 94.

Ojo, V., Ayorinde, K. L., T. R. Fayeye and Josiah, B. O. (2012). Effect of Egg weight on Hatchability and Growth Performance of the Japanese Quail in Nigeria. Nigerian Journal of Genetics. 26: 180-185. Publisher: The Genetic Society of Nigeria. 
Sarı, M., Serpil Işık , Önk, K., Tilki, M.and Kırmızıbayrak, T. (2012). Effects of layer age and different plumage colors on external and internal egg quality characteristics in Japanese quails (Coturnix coturnix japonica). Arch.Geflügelk., 76( 4): 254- 258.

SAS Institute (2012). SAS/STAT user`s Guide Statistics. SAS. Institute INC., cary, NC, U.S.A.

Seker, I., S. Kul, M. Bayraktar, O. Yildirim, (2005). Effect of layer age on some egg quality characteristics and egg production in Japanese quail (Coturnix coturnix japonica). J. Fac. Vet. Med. Istanbul Univ. 31, 129-138.

Sezer, M., (2007). Heritability of exterior egg quality traits in Japanese quails. Journal of Applied Biological Sci. 1, 37-40.

Sola-Ojo, F.E., Toye, A. A., Ayorinde, K. L., and Afolayan, O. F. (2011). Relationship between egg weight and subsequent body weight in Fulani ecotype chicken.Global Journ. of Agric. Sci. 10 (2):103-109.

Troutman, C. (2012). What are the benefits of quail. Retrieved online on 11/09/2013 http://www.ehow.com/list 6671158 benefits-quail-eggs_html\#page=1

Uluocak, A. N., Okan, F., Efe, E. and Nacar, H. (1995). Bdlddrcdn yumurtalardnda bazd iç ve ddş kalite özellikleri ile bunlardn yaşa göre değişimi. Turkish Journal of Veterinary and Animal Science, 19: 181-185.

Yilmaz, A., and Caglayan, T. (2008). Egg weight, shape index, hatching weight and correlations among these traits in Japanese quail (Coturnix coturnix japonica) with different colored plumages. Firat University Veterinary Journal of Health Sciences,22: 05-08.

Yilmaz, A., Tepeli, C. and Caglayan, T. (2011). External and internal egg quality characteristics in Japanese quails of different plumage color lines. Journal of Food, Agriculture \& Environment, 9: 375-379. 